\title{
MEASURING THE EVOLUTION OF STRIKE MOVEMENTS
}

Strike activity is clearly the least studied aspect of the history of labor movements, yet it may be the most revealing index of the situation and outlook of actual workers. Moreover strike activity has an important history of its own, related to but not described by the history of organized labor. Strikes have evolved. Various groups of workers developed an ability to mount new kinds of strikes at different times. In order to grasp this evolution we need some clear means of measurement. What follows is an effort to suggest some criteria, many of them obvious enough. The essay results from an ongoing study of workers in France, Belgium, Germany and Britain in the two decades before World War I. But while examples are chosen primarily from this area and period, the effort is meant to be quite open-ended. There is no need to expect uniform patterns of strike activity in a given stage of industrialization; but there is every reason to hope that sufficiently general standards of measurement can be developed to measure key differences and to specify problems that require deeper study in terms of fundamental causation.

The focus is on strikes as an expression of workers' grievances, which means that we are more concerned with evaluating strikers than strikes. In talking about an evolution in strikes we are really talking about extremely important changes in workers' value systems as well as in their objective conditions. The notion of an evolution involves some problems in terminology. It is necessary to claim that some strikes are more "sophisticated" than others - that is, that they have evolved farther along the lines that strikes in general ultimately followed. They are thus more modern, for as we shall see the evolution of strike demands relates to the development of more modernized attitudes such as a belief in progress. But I avoid using the word "modernization" directly lest it complicate the discussion; hence the use of "sophistication". It is, unfortunately, a loaded word, but short of inventing a new term I must simply urge that it be read without subjective connotations. A more sophisticated strike is not necessarily a better strike, 
and its participants not necessarily more intelligent. Important aspects of the evolution of strikes can easily be judged unfortunate, particularly as they involved growing acceptance of the industrial order. The need is for a descriptive model, not a set of value judgments. This need is enhanced by the information available on the characteristics of preindustrial protest, which has in fact assumed knowledge of the characteristics of industrial protest in advance of much empirical work.

\section{PREINDUSTRIAL PROTEST}

For some time now various historians, particularly in Britain and the United states, have been developing models of "industrial" and "preindustrial" protest - or "primitive" and "modern". George Rudé's studies of crowds, Eric Hobsbawm's analysis of peasant protest and the early labor sects, and recently Charles Tilly's more theoretical statements ${ }^{1}$ have provided unusually clear conceptual generalizations. They are not without some disagreements. Tilly for example calls attention to a high, if premodern, political content in preindustrial bread and grain riots. But on the whole they fit together rather nicely. The preindustrial protest, aspects of which developed in western Europe at the end of the Middle Ages, relied on the riot. It was usually localized, though it might spread widely from one locality to the next. It was not formally organized. It depended more on community than on class affiliation, though it typically pitted poor against rich. Hence artisans and villagers, who belonged to tightly knit communities, were at the forefront of such protest, as opposed to more transient types. Above all it was backward looking, appealing to past rights and values. Artisans recalled the principles of the ideal guild; peasants those of an ideal village. Their past may never have existed in such pure form, but it was ardently claimed. Even more modest economic agitation looked to the past. Bread rioters sought the prices that had prevailed a few years before, tax rioters demanded a return to previous levels. Hence for obvious reasons preindustrial protest could not occur in prosperous years. It depended on economic difficulties, when the present could be measured against the past and found wanting.

Many historians will find fault with this general picture. Certainly we can see in the 18th century a number of individual cases in which

1 George Rudé, The Crowd in History (New York, 1964); Eric Hobsbawm, Primitive Rebels: Studies in Archaic Forms of Social Movement in the 19th and 20th Centuries (New York, 1965); Charles Tilly, "Collective Violence in European Perspective", in: Hugh Davis Graham and Ted Robert Gurr, eds, Violence in America (New York, 1969), pp. 4-44. 
protest patterns do not fit this model. Small groups of artisans struck and bargained for higher wages in times of prosperity. ${ }^{1}$ And as we move into the 19th century, complications abound. More and more groups, again led by urban artisans, turned to more modern forms of protest. It has even been argued that Luddism, which seems a classically premodern response to industrialization, was in fact transitional toward newer forms. ${ }^{2}$ The craftsmen included in Aguet's study of French strikes during the July Monarchy ${ }^{3}$ had developed an ability to agitate in good years for higher wages and other new benefits. Industrial workers in France seemed, when they were able to protest at all, to conform more closely to preindustrial patterns, insofar as they stirred only in bad years, mainly demanding a return to conditions that prevailed in the recent past. ${ }^{4}$ Other groups probably oscillated, reverting to preindustrial forms in bad years but experimenting with new demands at other times. Even in bad years, as Rudé has noted, protest became increasingly "transitional" up through 1848.

But on the whole the model seems valid, for lower-class protest, at least with regard to England and France, from which most of the evidence comes to date, and probably with regard to other countries as well. ${ }^{5}$ It goes some way toward dealing with generalizations offered by various social scientists who purport at least to refer to the European experience. ${ }^{6}$ Preindustrial protest, which lasts into the early industrial period, does not result primarily from dislocations caused by rapid urban development. Aside from a few centers - Berlin, Marseilles which drew unusually large numbers of immigrants from unusual distances, and in which "outsiders" may have taken an unusually

1 Eric Hobsbawm, "The Machine Breakers", in Labouring Men (New York, 1967), pp. 7-26.

2 E. P. Thompson, The Making of the English Working Class (New York, 1963). 3 Jean-Pierre Aguet, Les Grèves sous la Monarchie de Juillet (Geneva, 1954). 4 Peter N. Stearns, "Patterns of Industrial Strike Activity in France during the July Monarchy", in: American Historical Review, LXX (1964-65), pp. 371-94. 5 Alan H. Adamson, "Monoculture and Village Decay in British Guiana: 1854-1872", in: Journal of Social History, III (1969-70), pp. 386-405; Richard Tilly, "Popular Disorders in Nineteenth-Century Germany: A Preliminary Survey", in: Journal of Social History, IV (1970-71), pp. 1-40.

- G. Ridker, "Discontent and Economic Growth", in: Economic Development and Cultural Change, XI (1962-63), pp. 1-13; Mancur Olson, "Rapid Growth as a Destabilizing Force", in: Journal of Economic History, XXIII (1963), pP. 529-52; Ted Gurr, The Condition of Civil Violence: First Test of a Casual Model [Center of International Studies, Princeton University, Research Monograph No 28] (Princeton, 1967); James C. Davies, "The J-Curve of Rising and Declining Satisfactions as a Cause of Some Great Revolutions and a Contained Rebellion", in: Violence in America, op. cit., pp. 690-730. 
prominent role in agitation, 1 protest remained most likely among established groups, probably more likely in older centers than in new. ${ }^{2}$ Immiseration, the other thesis sometimes advanced in the social sciences, also proves inadequate, for the most miserable groups did not usually rebel and many protesters were not victims of longterm economic deterioration. Above all, preindustrial protest is not a function of rapidly rising expectations. For in learning about the nature of preindustrial protest we have learned a great deal about the values of preindustrial people, not all of it surprising to be sure. The absence of a belief in progress or in new rights - which of course was quite compatible with a vigorous sense of justice - is one of their most striking features.

\section{II}

\section{THE NATURE OF MODERN PROTEST}

But what of modern protest? Oddly, most of the generalizations define modern protest more implicitly than explicitly and study it not at all. Rudé sees 1848 as the last expression of preindustrial protest, and he stops there. Tilly defines modern protest more fully but we are only beginning to get examples of his empirical work on the subject. ${ }^{3}$ The characteristics of modern protest seem obvious, for they are the mirror images of the features stressed in the preindustrial period. Modern protest is forward-looking, demanding new rights instead of old. It is organized, large scale, class-based. It takes place in good times, not bad.4

And of course modern protest is political, demanding political rights and utilizing the political process. The present essay does not directly deal with this aspect of the protest modernization question. Strikes in three of the four countries considered rarely had overt political content before 1914. There was political agitation in Germany, including demonstrations and some rioting over the suffrage limitations.

1 William Sewell, "La Classe ouvrière de Marseille sous la Seconde Republique: Structure sociale et comportement politique", in: Mouvement Social, No 76 (1971), pp. 27-65.

2 Rémi Gossez, "Diversité des antagonismes sociaux vers le milieu du XIXe siècle", in: Revue Economique, VII (1956), pp. 439-57; Rémi Gossez, Les Ouvriers de Paris (Paris, 1966); R. Tilly, "Popular Disorders", loc. cit.

3 Charles Tilly and Edward Shorter, "The Shape of Strikes in France 1830-1960", in: Comparative Studies in Society and History, XIII (1971), pp. 60-86; Charles Tilly and Edward Shorter, "Le Déclin de la grève violente en France de 1890 à 1935", in: Mouvement Social, No 76, pp. 96-118.

4 Ch. Tilly, "Collective Violence", loc. cit. 
A strike was called against militarism in France, in 1911, but it did not win much support. ${ }^{1}$ Of course many, probably most, strikers were politically aware; of course strikes had political consequences. And it may be that as we learn more about strikes we can glean political intent from such indices as violence towards policemen. It is also possible that even apparently economic strikes were influenced by political considerations; careful evaluation of long series of strikes may reveal some correlation between intensity of strike activity and major election years.

But for the moment, at least in the period and areas covered, strike sophistication and political sophistication remain largely separate topics. A study of strikes may even raise some doubts about the automatic congruity of these two measurements of working-class outlook. Leather and textile workers in Mazamet and Graulhet, in Southern France, developed advanced forms of strikes and strike demands early in the twentieth century, while remaining conservative and deferential in their political behavior. Miners in Montceau converted to socialism after massive strikes at the turn of the century, but remained largely apart from strikes thereafter. ${ }^{2}$ Miners in the South began to vote socialist when they learned that they were unable to win significant gains in strikes, and were therefore absent from the great mining agitation that swept other areas from 1900 onward. $^{3}$ These are scattered examples, to be sure, and many counter examples could be uncovered. But there are larger problems; Belgium and Germany, where political sophistication can be seen as more advanced than in France and Britain - on grounds not only of socialist strength but also of percentage of eligible voters voting ${ }^{4}$ - had generally less sophisticated strikes. From which I conclude that politicization may be easier to acquire than the kind of value transformation necessary to produce sophisticated strike demands.

This conclusion is also supported by the high political content in Russian and Southern European strikes before 1914, where economic demands were understandably less advanced. It may be supported further by the experience of West European countries more recently, where strikes continue to show increasing sophistication while outright

1 Peter N. Stearns, Revolutionary Syndicalism and French Labor: A Cause without rebels (New Brunswick, N.J., 1971).

2 Paul Bureau, Le Contrat du travail (Paris, 1902), p. 27 and passim; Léon Laroche, Montceau-les-Mines (Montceau-les-Mines, 1924).

3 Leo Loubère, "Coal Miners, Strikes and Politics in Lower Languedoc, 18801914", in: Journal of Social History, II (1968-69), pp. 25-50.

4 Neal Blewett, "The Franchise in the United Kingdom 1885-1918", in: Past and Present, No 32 (1965), pp. 27-56. 
political participation by workers recedes. ${ }^{1} \mathrm{I}$ am inclined to add also, for the area and period I am studying directly that politicization can impede strike sophistication, by providing an alternate focus in terms of values and social outlets. The Belgian worker who could go to one of the Maisons du peuple for his groceries, his theater, his newspaper, even advice to the lovelorn, might be diverted from complaining about his immediate economic situation. ${ }^{2}$ The German miner Max Lotz gives us a specific example of this sort of exchange. He claims that his work conditions are deteriorating massively, but he revealingly adds that nothing can compensate for this, that no amount of money will suffice. Implicitly he thus says that normal strike goals will be a waste of time. "What is my meaning in this great world plan where brutal physical and psychological forces feast themselves in orgies? Nothing! [ . . ] Only Social Democratic activities could give me goals and offer me economic security too, so that I may attempt my plans. I therefore adhere to socialism with every fiber of courage and idealism." 3 For this kind of worker socialism had become a new religion. It is not accidental that socialism of this sort spread more widely in countries where anticlericalism had advanced less far before socialism's advent, though not of course in areas where religion retained its greatest traditional hold. It is therefore not surprising that the transformation of material values, which is what strike activity most clearly reflects, progressed less rapidly.

The above generalizations are offered for discussion, and they obviously demand further study, for at this point they suggest only some doubts about any facile conclusions about the relationship between politics and protest modernization. One could be an ardent socialist but an "unmodernized" striker and vice versa.

Let us return to strikes themselves, not claiming that they offer the only measurement of working-class protest, for politics obviously should not be ignored, but recognizing that they constitute an important element. We can readily grant that strikes have received little attention from historians. A few studies cover the period after World

1 John H. Goldthorpe and others, The Affluent Worker in the Class Structure (Cambridge, 1969), and The Affluent Worker: Political Attitudes and Behaviour (Cambridge, 1968); Robert McKenzie and Allan Silver, Angels in Marble: Working Class Conservatives in Urban England (London, 1968).

2 Guenther Roth, The Social Democrates in Imperial Germany: A Study in Working-Class Isolation and National Integration (Totowa, N. J., 1963); Hans Gehrig and Heinrich Waentig, eds, Belgiens Volkswirtschaft (Leipzig, 1918); Marc-Antoine Pierson, Histoire du socialisme en Belgique (Brussels, 1953).

Adolf Levenstein, Aus der Tiefe, Arbeiterbriefe (Berlin, 1905), pp. 70-71. 
War I and offer some important theoretical observations. ${ }^{1}$ For the earlier period there are some admirable studies of individual strikes, ${ }^{2}$ but studies of larger strike phenomena, of larger movements of strikes, are almost non-existent. ${ }^{3}$ Ironically, we therefore lack the knowledge we need to confirm or qualify generalizations about the nature of modern direct-action protest. We know that strikes replace riots as the main form of direct-action protest in the advanced industrial countries, but we know little about this major aspect of workers' lives. My own interest in strikes lies more in what they say about workers' values than in the issue of protest forms in the abstract. But the topics are closely interrelated, for changes in the nature of strikes reflected profound changes in the way workers thought about their world.

This returns us to the protest model, with politics for the moment left out. I believe that the model of "modern" protest helps guide us in choosing criteria for the measurement of the evolution of strikes, but is itself an exaggerated statement. It implies a vast change in outlook that could not come about overnight. We should immediately be suspicious of claims that the common people moved from backward-looking protest to protest based on a belief in progress in a three year period, as one recent essay suggests. ${ }^{4}$ Belief in progress was a major departure for the working classes, contrary to their traditions and much of their continuing experience. Strike demands moved toward this belief only slowly. A long transitional period was needed. Strikes before World War I remained within this transition. They are not preindustrial, but they require a model of their own rather than one which most accurately applies to protest after World War II.

1 Tilly and Shorter, "The Shape of Strikes", loc. cit.; R. Goetz-Girey, Le Mouvement des grèves en France, 1919-1962 (Paris, 1965); K. G. J. C. Knowles, Strikes - A Study in Industrial Conflict (Oxford, 1948); Robert Gubbels, La Grève, phénomène de civilisation (Brussels, 1962).

2 Good examples of the genre are Dieter Fricke, Der Ruhrbergarbeiter-Streik von 1905 (Berlin, 1955); Helmut Bleiber, "Die Moabiter Unruhen 1910", in: Zeitschrift für Geschichtswissenschaft, III (1955), pp. 173-211. Still essentially descriptive, though dealing with a series of strikes: Jack Schiefer, Wirtschaftliche Streiks und Aussperrungen in Rheinland und Westfalen 1870-1932 (n.p., n.d.); Léon Delsinne, Les Grèves générales au XXe siècle en Belgique (Brussels, 1965); Léon Linotte, Les Manifestations et les grèves dans la province de Liège de 1831-1914 (Liège, 1965). E. H. Phelps Brown, The Growth of British Industrial Relations (London, 1959) is more analytical, but it lacks a full statistical base and its chronological coverage is limited to a few years.

3 Tilly and Shorter, "The Shape of Strikes", and "Le Déclin de la grève violente", loc. cit.; more will be forthcoming from this ambitious project on unrest in France.

" Charles Tilly, "The Changing Place of Collective Violence", in: Melvin Richter, ed., Essays in Theory and History (Cambridge, Mass., 1970), pp. 129-164. 
One or two sources of confusion must be mentioned at the outset. The progressive model of protest fits the goals of labor organizations in the later nineteenth century much better than the goals of strikes. The pronouncements of trade union leaders whether socialist or reformist or even syndicalist were undeniably progressive. They urged strikers to seek better wages and above all better working conditions and hours. Their advice about strikes became increasingly similar after 1900, despite deep ideological differences in general. They urged careful planning and organization. They appealed to workers to shun unimportant issues in favor of basic improvements. They urged concentration on better conditions and hours because such gains were easier to preserve and more fundamental to workers' well-being than mere wage improvements. They tried to impose greater controls over strikes. This was easier to accomplish in Britain or Germany where unions were more bureaucratized, with larger strike funds to influence worker behavior, than in syndicalist France, but everywhere the effort went forward. French revolutionary syndicalist unions developed strike funds, tried to encourage negotiation and discourage violence - like the leader of the leatherworkers, Barthey, who told strikers in Graulhet: "you can cut wires, unload wagons, but this won't end the strike; an agreement can come only from discussion" - and certainly tried to push workers to demands that seemed more constructive. ${ }^{1}$

Efforts of this sort were extremely important, and they undeniably influenced strikes. But the policies of union and other leaders cannot be taken at face value as to actual strikes and strikers. Where leaders pushed too hard along the "constructive" path they faced rebellions from their constituents; this is an important theme in strikes in Germany and Britain right before World War I. ${ }^{2}$ Hence strike patterns did not move uniformly in the directions urged by formal labor leaders. Efforts at reduction of hours of work, for example, often declined in significance. Strikes over personal issues, uniformly deplored by experienced labor leaders, held their own or even increased until after World War I. This was one cause of the increasing uneasiness about strikes manifested most obviously by syndicalist leaders before the War. Strikers and leaders were not responding to the same forces. Most strikes, even major ones prepared by organizations, had a strong spontaneous element - for example the French railroad strike

1 Syndicat national des travailleurs des chemins de fer, Rapport (Paris, 1909), p. 93.

2 Phillip A. Koller, Das Massen- und Führerproblem in den Freien Gewerkschaften (Tübingen, 1920); George Dangerfield, The Strange Death of Liberal England 1910-1914 (New York, 1961), pp. 214-332; Phelps Brown, The Growth of British Industrial Relations. 
of 1910 , or the German mine strike of 1905 , or the British transport strike of 1911. This makes generalizations about the nature of protest in this period more complex than has usually been realized.

\section{III}

\section{CRITERIA FOR MEASUREMENT}

In dealing with actual strikes we are happily provided with considerable statistical evidence in all the advanced industrial countries. By the 1890s governments gathered information about the incidence, size, duration, demands and results of strikes. British material is less adequate than German, German less than French, but in all cases there is at least some basis for quantitative assessments of strikes. A number of caveats are also needed. Government statisticians often erred as to the results of strikes. German trade unionists insisted that they undercounted strike victories. ${ }^{1}$ They were often badly informed on strike issues, seizing on ultimate demands rather than the actual initial causes of a strike and usually simplifying the list of demands. They undercounted strikes themselves, perhaps by as much as $10 \%$. They often divided what were essentially single strikes, across a city for example, into distinct industries, thus reducing the real size of strikes. ${ }^{2}$ These and other problems reduce the value of any purely quantitative calculations. I have found it impossible to develop a sufficiently subtle interpretive framework relying on statistical materials alone; other evidence, derived from more detailed study of individual strikes, is essential, and while it is potentially quantifiable the practical difficulties are considerable. What follows is frankly a mixture frowned upon by some purists who seek numerical statements and correlations alone.

We can now set forth the goals and methods of our study more precisely. We assume that the strike movement was evolving in the industrial countries, that its characteristics were changing if only gradually. We must try to identify these changes. We can ask two further questions. Was the change occurring fairly uniformly in the most advanced industrial countries or were there variations because of different rates of industrialization or types of industrialization or even more basic distinctions of national character? It has been argued for example that French strikes reflected French political traditions and

1 Carl Legien, "Die Ergebnisse der ämtlichen und der gewerkschaftlichen Streikstatistik", in: Die Neue Zeit, XXII, 1 (1903-04), pp. 475-6.

3 Several of these problems are discussed in Tilly and Shorter, "The Shape of Strikes"; see also "Incidence and Duration of Industrial Disputes", in: International Labour Review, LVII (1958), p. 456. 
lack of industrial concentration. ${ }^{1}$ Within a single region or country, we can ask about differential strike evolution according to type of industry, for some workers may have been able to develop newer strike forms more readily than others. ${ }^{2}$

What we need, then, is a set of measurements, which we can then apply to specific strike patterns. Measuring strikes is not new, of course, but it has usually been from an economic standpoint, stressing numbers of man days lost. ${ }^{3}$ As we will see shortly, this is not a satisfactory approach for understanding what strikes meant to workers, or therefore, for constructing a protest model, because it depends on too many factors beyond workers' control. A recent effort to deal with strikes though much more subtle, per se, suffers from some of the same drawbacks, in the emphasis it gives to man days lost and its lack of full consideration of strike demands. ${ }^{4}$ Discussions of strike methods also exist; what follows does not attempt to list these (sitdowns versus series strikes versus ca'canny) ${ }^{5}$ directly in terms of sophistication, though perhaps the effort should ultimately be attempted.

Some of the measurements of strikes are obvious and relate to those used by economists and students of strike methods. The larger strike shows more organizing ability and more group or class consciousness than the smaller strike. We know that strikes have grown larger on the average, ${ }^{6}$ which is not of course to neglect the importance of some individual giant strikes earlier in the nineteenth century. Applying this criterion over time raises no real problems. It may however distort an evaluation of differences at a given time among nations and even more industries. For the area or industry with unusual concentrations of workers naturally produces larger strikes. Some countries regularly produce larger strikes than others, over a long period, without being noticeably more advanced in other respects. For the moment it is difficult to integrate such differences into the general argument, though within a given country this criteria still apply. Differences among industries pose less problems. The fact that coal mining regu-

1 Val R. Lorwin, "Reflections on the History of the French and American Labor Movement", in: Journal of Economic History, XVII (1957), p. 25 and passim; Arthur M. Ross and Paul Hartman, Changing Patterns of Industrial Conflict (New York, 1960), pp. 89, 116.

2 Clark Kerr and Abraham Siegel, "The Interindustry Propensity to Strike An International Comparison", in: A. Kornhaus, R. Dubin, and A. M. Ross, eds, Patterns of Industrial Conflict (New York, 1954).

3 Ross and Hartman, Changing Patterns.

- Tilly and Shorter, "The Shape of Strikes".

5 Knowles, Strikes.

- Tilly and Shorter, "The Shape of Strikes". 
larly produces larger strikes than printing is not necessarily a measurement of different levels of sophistication. There are several possible controls which alleviate this problem without removing it entirely.

Number of companies affected by an average strike is one obvious control. The large strike that does not exceed the bounds of a single company probably does not reflect the same level of class or group consciousness as a smaller strike that spread more widely, at least before World War I. Hence when we know that most large mining strikes cut across a number of companies, we are much further along in our understanding of the sophistication involved. The number of companies measurement breaks down only in two major cases: obviously workers in a company town may conduct quite a sophisticated strike without being able to break the bounds of a single company. Several quarry strikes in Belgium and Britain fall in this category. For metallurgical workers employed by giants like Krupp or Le Creusot, a one-company strike was itself a major achievement. By this token, as more giant firms developed, the number-of-companies criterion becomes less useful. Even before World War I, on the other hand, casual workers whose employment regularly shifted from one company to another might strike against a number of companies without demonstrating much sophistication in other respects; it was simply impossible to single out an individual firm. Many dock strikes fall into this category. But on the whole a strike that affects more than one company reveals an ability to grasp more abstract issues and to organize on that basis. The one-company strike may be very necessary and quite consistent with a sophisticated consciousness, but often it reflected real limitations in workers' ability to formulate demands of general interest. When we realize that, between 1899 and 1914, 74\% of all French strikes and $86 \%$ of all Belgian strikes were one-company efforts, we know that this problem of limitations may be acute. Within a given country the criterion helps distinguish industrial differences; whereas British building trade workers almost never conducted a one-company effort by 1914 , cloth workers did so in about a quarter of their strikes. ${ }^{1}$

Supplementing the number of companies as a measurement is the criterion of regional coverage. Outside of Britain remarkably few groups of workers were able to spread a strike beyond a single locality before 1914. Miners could, although not in Germany, not at the national level yet. Dock and maritime workers could, though limitations on this ability in Germany and Belgium reflect other comparative differences

l Direction du travail, Statistique des grèves et recours a conciliation, 1899-1914 (Paris, 1900-15); Board of Trade, Annual Reports on Strikes and Lockouts (London, 1900-15); Revue du travail (Belgium), 1899-1914. 
with the more advanced dockers and sailors of France and Britain. Textile workers rarely could, except among cotton workers in Britain on the regional basis of Lancashire. French and British railroad workers could to some degree, but only British rail workers, and only after 1909, developed a solid ability in this regard. Construction workers could not get beyond the locality except in Germany. Metallurgical workers could exceptionally rise on a regional basis, never on a national one. So this measurement by geographical extent, though crude, is important. It reflects of course the degree of unionization and also of employer organization; it is not a pure measurement of workers' abilities. But it does tell us when some groups of workers overcame handicaps that others could not; it does measure the spread of class consciousness.

Percentage of the relevant workers involved in a strike is another useful supplement to the basic criterion of strike size. It is reasonable to presume that maturing consciousness and ability to organize will produce an increase in the percentage of workers striking. It is not, of course, easy to obtain reliable information on this point, and some national statistics did not make the effort. And even with reliable information the problem of defining the relevant work group is troublesome. Many skilled workers operated still on the basis of intense loyalty to a limited craft. If in a shoe factory all 17 mounters strike (and they were the most agitated group in this industry) but no one else from the factory joins them, how much do we know? The measurement is relevant but must be used with caution.

I think we can agree that a large strike, spreading over many companies and into various areas and involving a high percentage of the relevant work force, shows more sophistication than a strike which is more limited in these respects. We can expect strike patterns to evolve in this direction, in whole countries and within key industries. We can also over the long haul expect strike rates to go down. ${ }^{1}$ As workers become better organized they refrain from frequent strikes in the interests of larger, well-prepared efforts. This distinguishes French strikes after World War I, for example, from strikes before the war. ${ }^{2}$ But for shortrun judgments, particularly before 1914, strike frequency has some real ambiguities. In the first place frequent striking almost surely shows a more advanced worker mentality than no

1 Goetz-Girey, Le Mouvement des grèves en France; Tilly and Shorter, "The Shape of Strikes".

2 As with strike size, there are enduring national differences in strike frequency: Britain has long been an area of high frequency, the United States and Scandinavia middle-range, Germany, low. Again measurement must occur within these frameworks, the causes of which deserve serious investigation. 
striking at all. French bakers struck rarely because they still lacked a consciousness of themselves as workers. Correspondingly a spurt of strikes may signal a major advance in thinking. We can, however, measure before World War I in some groups of workers an evolution toward less frequent strikes. Dock workers burst forth often with an initial exuberance that led to many strikes, only to learn that this was self-defeating; such was the pattern in Marseilles before and after 1904..$^{1}$ Construction workers in Berlin and Paris conducted an amazing variety of strikes after 1905, most of them small; this involved a deliberate strategy, particularly in Paris, of picking off one company at a time, but it reflected also the high and rather undisciplined passions of workers themselves, who turned any sudden grievance into a strike. Within three years (by 1909) employer resistance and an economic downturn taught workers to restrain themselves. They were not defeated. They did not withdraw from agitation. But they did learn to save themselves for more solid efforts, and they became in this sense more sophisticated. ${ }^{2}$ We can here recognize that sophistication involved considerable bowing to the exigencies of organization, a real loss of spontaneity, and may therefore be deplored, depending on one's point of view.

Organization figures directly in other measurements of strike sophistication, and it is of course directly invoked in all the models of modern protest. Strikes are normally more organized than riots, which is one obvious distinction between the industrial and preindustrial forms of protest. At the turn of the century the most basic organizational question to ask about strikes is whether any planning preceded the outburst. Well into the twentieth century we find countless strikes resulting from a spontaneous reaction to some development on the job - an announced pay cut, a dismissal, an insult; at an extreme, the spontaneous strikers lacked the ability to formulate a grievance. They were angry without doubt. Sometimes they vented their anger in immediate violence against employers or foremen, which directly recalled the preindustrial protest patterns just referred to. ${ }^{3}$ Bread riots in Northern France in 1910 showed even more directly the ability to revert to older patterns, for here merchants were attacked; spon-

1 André E. Sayous, Les Grèves de Marseille en 1904 (Paris, 1904); Antony Schoux, Des Grèves maritimes (Paris, 1910); Archives départementales des Bouches-du-Rhône, Marseilles, M6-2040 on the 1904 agitation, and M6-10824 on later patterns.

2 Fritz Paeplow, Zur Geschichte der deutschen Bauarbeiterbewegung (Berlin, n.d.); Zentralverband der Maurer u. Bauhilfsarbeiter Deutschlands, Jahrbuch 1910 (Hamburg, 1911); Raymond Joran, L'Organisation syndicale dans l'industrie des bâtiments (Paris, 1914).

3 Stearns, Revolutionary syndicalism, pp. 28-30. 
taneous outbursts, the bread riots ceased when the CGT tried to organize them. ${ }^{1}$ Still more spontaneous outbursts lacked significant violence but revealed strikers without sufficient experience and/or too frightened of their employer to put grievances into words. Strikes without demands distinctly declined after 1900, though we lack precise statistics. But strikes called without planning remained common. Often there was no knowledge of how to negotiate. Often there was no thought to funding. CGT officers complained increasingly of the telegrams they received, from workers whom they'd never heard from before, saying "strike called, send money". Here again, we lack precise statistical measurements of such strike characteristics. Size and frequency of strikes capture most of them indirectly. The badly planned strike was small and frequent. Growing experience with funding and bargaining were basic to measurable changes in the strike rate. In several sets of statistics we do have rates of involvement of union members in strikes, which gives some notion of levels of organizing ability. We should not of course assume that involvement of union members assures improved organization. Given the volatility of union membership - over $100 \%$ annually in many cases - the fact itself does not necessarily have much meaning. But it does serve as a rough guide. The fact that an important minority of strikes, even by 1914, took place without the involvement of a single union member usefully reminds us that both strikes and unions were still in an early stage in many respects.

Timing is an obvious criterion in assessing protest. Strikers who persisted in rising in bad times were less sophisticated than those who could hold off for prosperity, when the chances of success were immeasurably greater. By the 1900 s most workers, if able to protest at all, had learned this lesson, a historic one in the evolution of protest. But some workers and some areas were much more likely to rise in bad times than others - textile workers were much more susceptible than construction workers, for example - so the measurement remains useful.

\section{IV}

\section{PROBLEMS IN MEASUREMENT}

Four other formal aspects of strikes, all statistically measurable in theory, might aid an evaluation of sophistication levels but involve disadvantages which I find in some cases insuperable. It would be tempting to say that the lower the rates of failure in strikes, the more

1 Pierre du Marousseur, "La Vie chère et les grèves de consommateurs", in: La Réforme Sociale, I (1911), p. 730. 
sophisticated the strikers. We have already seen that sophistication involves in large part a recognition of what one has to do to maximize strike success, and in may instances I think low failure rates would reflect sophistication. A still more subtle measure in conjunction with this would be rates of compromise compared to rates of outright victory; we know that trade union involvement in strikes correlates, not surprisingly, with relatively low failure rates but also low rates of outright victory - unions meant compromise. ${ }^{1}$ But obviously these rates depend on employers as well as workers. A surprise strike by unsophisticated workers - one thinks of many of the early dock strikesoften won. French strike failure rates rose distinctly after 1910, despite prosperity - the reason reflected in part the involvement of new, inexperienced workers in the strike movement while "sophisticated" workers held back in favor of collective bargaining, but even more the growing intransigance and improved organization of the employers. ${ }^{2}$

Ability and willingness to negotiate might be another measurement of growing sophistication. I think it is true that several changes occurred in this regard before World War I, although not all of them are reflected in collected statistics. We have already noted that strikes in which workers simply did not know how to negotiate declined. With growing union involvement fewer workers were paralyzed by a fear of employer intimidation, for fewer would expect that their employer would simply outtalk them if they actually sat down with him. Negotiation demonstrably shifted away from the involvement of state agencies. In France $25 \%$ of all strikes until 1904 were conciliated by justices of the peace; thereafter the rate declined to a low of $2 \%$. German use of the Gewerbegerichte fell correspondingly. ${ }^{3}$ Both employers and workers learned to use their own resources in strike settlement, which increasingly involved collective bargaining. These changes in the rate and nature of negotiation have undeniable historical importance. They obviously relate to other strike characteristics. Growing size of strikes probably reflected, among many other things, an understanding among the more timid workers that bargaining was becoming possible and a more general realization that the larger the strike the better the probable bargain.

But I am loath to utilize bargaining directly as a measure of sophistication. It depended on employers as well as workers; it is useful to

1 Stearns, Revolutionary syndicalism, pp. 28-30.

2 Peter N. Stearns, "Against the Strike Threat: Employer Policy toward Labor Agitation in France, 1900-1914", in: Journal of Modern History, XL (1968), pp. 474-500.

3 Direction du travail, Statistique; Kaiserliches Statistisches Amt, Statistik über Streiks und Aussperrungen, 1899-1914. 
remember that employers also had their distinct stages in sophistication and that many, well beyond 1914, were too locked in tradition to contemplate negotiation. ${ }^{1}$ And the phenomenon is too loaded in favor of acceptance of the existing system. A minority of workers held out against the principle of negotiation. Their number or at least their voice did become weaker in France and probably in Germany between 1900 and 1914, but this is not a measure of changing sophistication. British workers after 1909 conducted something of a rebellion against their bargaining system, ${ }^{2}$ though it must be stressed that it was a limited revolt and led to new negotiated settlements; this was not a throwback to a less sophisticated consciousness but a sign of a new level of awareness. I do admit the fuzziness of my boundary line here. Other measurements of strike sophistication reflect acceptance of "the system" too. But I would argue that acceptance of the requirements of organized protest - the reduction of spontaneous outbursts - is an acceptance of the nature of the industrial system, not specifically of the capitalist system, whereas negotiation, though it also reflects a growing sense of realism as to how to end strikes with some tangible result, reflects a more limited and withdrawable accommodation to the capitalist system.

Violence falls in the same category in part, yet I think we have to take it more seriously. Violence is not recorded in official strike statistics and can be quantified only with great effort, through the use of police reports, newspapers and so on. I have not done this and in fact can offer only some impressions. Most serious studies of strikes suggest a marked decline in violence. I have tried to suggest a decline in French strikes even before World War I; a recent article rejects this but notes a definite drop by the 1920s. Violence in American strikes is down. $^{3}$ The longterm trend seems clear, following from better worker organization, more accommodating employers, and changes in the laws regulating strikes. I would maintain still that declining violence among key groups of French workers - dockers, Parisian construction workers, Fougères shoe workers, coal miners generally - even before

1 Lawrence Schofer, "Patterns of Labor Protest: Upper Silesia 1865-1914", in: Journal of Social History, V (1971-72), pp. 447-63.

${ }_{2}$ Phelps Brown, The Growth of British Industrial Relations; Industrial Council, Minutes of Evidence in Connection with their Enquiry into Industrial Agreements [Cd 6953] (London, 1913); Norman McKillop, The Lighted Flame: A History of the Associated Society of Locomotive Engineers and Firemen (London, 1950), pp. 91-8.

3 Philip Taft and Philip Ross, "American Labor Violence: Its Causes, Character, and Outcome", in: Davis and Graham, Violence in America, pp. 281-365; Tilly and Shorter, "Le Déclin de la grève violente"; Stearns, "Against the Strike Threat", loc. cit. 
1914 reflect some of these factors. It is obvious that as with negotiation violence depends not just on workers themselves, and this faults the criterion as a measurement of strikers if not strikes. It involves some similar problems of bias; the decline of violence may be seen as a bad thing or as different from somewhat more objective measurements of sophistication. It is also difficult to use as a shortterm measure. British strike violence rose dramatically between 1909 and 1912. German strike violence rose as well. We can keep the longer term trends in mind. We can usefully note also that most strike violence pits worker against worker, striker against non-striker, so that a decline in violence usually means improved organization and class consciousness. This was developing for example among French miners by 1912, as they learned to spread their strikes across whole basins without sending gangs of workers to intimidate their fellows. But for any shortterm evaluation, and certainly for a discussion of strikes around 1912, violence must probably be omitted.

Strikes have, in the twentieth century as a whole, become shorter. And duration is easily measurable from the strike statistics. It can be argued that sophisticated strikers are sufficiently experienced and organized to win quickly or to know that their chances are poor - hence brevity, on the average, reflects sophistication. I think this pattern has some validity before 1.914. German strikes were longer than French, and this follows from their lower level of sophistication in other respects. But the weakness of this measurement, for an early period in the strike movement, is obvious. It depends on employers as well as workers. It can be argued that workers well enough organized and sufficiently aggrieved to hold out against a recalcitrant employer demonstrate a rather high level of sophistication. Certainly many short strikes followed from the confusion and inexperience of the workers involved. So I am leery of the duration criterion for the period under consideration. Hence, as mentioned above, the use of man-days lost, though important for measuring the strike's impact on the economy, has drawbacks in terms of judging a strike from the strikers' standpoint.

\section{$\mathrm{V}$ \\ GOALS OF STRIKES}

Strikes can be much better evaluated in terms of the demands raised. We need an interpretative framework here, for most studies of strikes to date have confined themselves to the more formal aspects, such as size and duration. But these aspects do not suffice in terms of judging from the strikers' standpoint, and I think we can advance a concep- 
tualization that will include demands of pre-World War I strikes, leaving aside relatively rare issues such as political grievances. One common measurement serves as a useful beginning. The defensive wage strike, the strike against a direct cut in pay, was a minority phenomenon but by no means unimportant. Any given defensive wage strike can simply denote unusually harsh economic conditions or a very severe employer (for the tone of wage cut announcements might matter as much as the money). But an unusual incidence of such strikes in an area or industry almost certainly indicates a weak tactical sense on the part of workers and quite possibly an inability to phrase more positive demands - that is, a lack of more sophisticated expectations. Qualitative evidence indicates clearly that many workers did not positively seek or expect wage raises or pursued them only individually. ${ }^{1}$ Workers themselves often commented on those of their colleagues who were delighted if their wages stretched past subsistence needs to an occasional pack of cigarettes. ${ }^{2}$ So when we know that German workers conducted more defensive wage strikes than French (and that the rate of such strikes did not fall after 1900, in contrast to the French situation) we know something important about differences in outlook and protest capability.

A large number of strikes (though involving a less impressive percentage of strikes) occurred over personal issues - up to $30 \%$ of the total in Germany, a bit less in France. These strikes were directed against individual directors, foremen, or workers, asking for their dismissal, or for the rehiring of individual workers or, more rarely, foremen. These strikes were obviously defensive in tone, asking for a redress of immediate grievances and implying a demand for restoration of past standards. This already suggests the possibility of a lack of progressive consciousness. More important is the personalization on which these strikes depended. The strikes reflected problems of the greatest importance, problems indeed which, at least in Germany, loomed largest in the workers' minds. ${ }^{3}$ More direct dissatisfaction about the work situation came through in these demands than in any other large category. Hatred of being bossed around and treated with growing anonymity, resentment against efforts to increase the pace of work (expressed often in demands that workers fired for inadequate production be rehired), fear of unemployment due to new work rules, resentment of employer greed - these and many other grievances

1 Peter N. Stearns, "Adaptation to Industrialization: German Workers as a Test Case", in: Central European History, III (1970), pp. 303-31.

2 Levenstein, Aus der Tiefe, pp. 60-63.

3 Stearns, "Adaptation to Industrialization", loc. cit.; Adolf Levenstein, Die Arbeiterfrage (Munich, 1912). 
caused the rash of personal issue strikes. But the issues were not expressed as issues, in any general way. The personal spark was essential, and the demands related to persons alone.

The two other large categories of demands (usually broken down somewhat in the official statistics) were conditions of work, including particularly demands for a reduction in hours, and offensive wage demands. Both categories represented a greater sophistication in expectations than the two previously discussed, but both require some further distinctions.

The most important point unfortunately takes us away from statistical precision. Any serious inquiry into offensive wage strikes reveals great variation in the type of expectations involved. Many offensive wage strikes, including some of great importance such as the French mine strike of 1902 and most of the great British strikes after 1909, were not really directed toward new levels of pay. They wanted restoration of old levels. At their simplest such strikes occurred after a slump, when conditions were improving, and asked that the preslump wages be reinstated. They were thus essentially defensive in tone, and differed from a defensive strike only in timing. The French mine strike of 1902 was somewhat more subtle. The miners had lost traditional bonuses, and struck to have their wages raised in compensation. The trigger for the French rail strike in 1910 was a reduction in overtime in the Parisian maintenance shops; again the demand was for a raise to compensate. Textile workers in all countries seem to have been unusually insistent on pay raises - until the reasons are investigated. A rash of strikes for raises in France between 1900 and 1904 was caused by the law reducing the hours of work; what was demanded was a raise to compensate, not to provide a really new level of pay. Textile strikes in many countries in 1910 followed the 1908-9 slump and were essentially defensive. But most typical of the industry was the strike for a raise to compensate for shoddy materials, the use of which, on the characteristic piece rate system, reduced pay. This, rather than an active desire for a higher standard of living, motivated most disputes even in Lancashire. ${ }^{1}$ In any industry where the piece rate prevailed - metals is the most important case ${ }^{2}$ - many wage strikes sought to compensate for changes in rates; the request for a

1 Bolton and District Operative Cotton Spinners Provincial Association, Annuals Reports, $1890-1914$.

2 Dora Landé, Arbeits- und Lohnverhältnisse in der Berliner Maschinenindustrie zu Beginn des 20. Jahrhunderts (Leipzig, 1910); Ludwig Bernhard, Die Akkordarbeit in Deutschland (Leipzig, 1903); Clemens Heiss, "Die Entlöhnungsmethoden in der deutscher Metallindustrie", in: Jahrbuch für Gesetzgebung, Verwaltung und Volkswirtschaft im Deutschen Reich, 1913, pp. 1475-84. 
raise was not truly offensive or at least not necessarily so. Such strikes were essential and important; they often expressed grievances that went well beyond wages alone; but they do not demonstrate the attachment to material progress that a genuinely offensive wage strike does.

After 1900 another major issue could generate wage strikes that were offensive in name only: inflation. A recent article claims ${ }^{1}$ that workers in this period had trouble perceiving inflation. It concludes that when inflation came to predominate, wage strikes decreased, arguing that outright offensive wage strikes were easier to mount and that a rise in prices confused the workers. I disagree, and have tried elsewhere to prove that a leveling off of wage strikes (specifically, in France after 1910) shows that inflation was easing up. ${ }^{2}$ I do agree that workers did not perceive inflation immediately. We know from a British account that housewives who were poor budget keepers often did not report price increases to their husbands for several years. ${ }^{3}$ In some cases they undoubtedly feared their husbands' wrath; a working-class novel has a worker telling his wife that while housekeeping was her responsibility, he was convinced that she was making a mess of it - and the novel was written in a period of massive inflation. 4 But eventually workers did perceive inflation. In France and to a lesser extent in Germany they began talking of it, in strikes, quite quickly - by 1905 . Even where, as apparently in Germany, ${ }^{\mathbf{5}}$ real wages did not go down, inflation would spur wage strikes because of the appearance of deterioration; and of course some workers in some years undoubtedly faced deterioration outright. In the long run inflation helped accustom workers to asking for steady improvements in money pay, but initially inflation could only induce a defensive reaction, and for many workers this remained true throughout the prewar period.

So most wage strikes labeled as offensive were in fact not. Of course workers were defending wages that were usually higher than traditional levels, for real wages had risen during the last decades of the 19th century. Of course in claiming past standards an actual raise might be involved - textile workers might be mistaken when they claimed their material condition was bad, or they might consciously be using the claim as a pretext for an outright raise. And the prevalence of defensive

1 Michelle Perrot, "Grèves, grévistes et conjoncture, Vieux problème, travaux neufs", in: Mouvement Social, No 63 (1968), pp. 109-24.

2 Stearns, Revolutionary Syndicalism, pp. 111-20.

3 Wil Jon Edwards, From the Valley I Came (London, 1958).

4 Robert Tressell, The Ragged Trousered Philanthropists (London, 1955), p. 58.

s Ashok Desai, Real Wages in Germany 1871-1913 (Oxford, 1968). 
justifications for raises reflects the difficulty of conducting strikes in this period, the need for reasonable argument that would not antagonize public opinion and had some chance of success with employers. Of course individual workers might seek raises even in situations where a collective demand did not emerge. Yet when all this is granted I think it is still true that large categories of workers had not yet passed to the stage where steady improvements in material conditions seemed possible or desirable. Hence we need a category "intermediate wage strike", admittedly not quantifiable save by a more laborious counting of strike reports than I have undertaken, to aid us in determining the sophistication of strike demands. The intermediate category is brought into fuller definition by the wage strikes which were truly offensive and the important categories of workers who did become capable of them.

Between strikes over conditions of work and genuinely offensive wage strikes there may be little to choose. Aside from demands for a reduction of hours, strikes over conditions of work were usually defensive - against a new system of fines or a work speedup - but I am loath to push this too far as a measure of sophistication. Defensive strikes were essential in this period when work conditions were changing so rapidly, and they could be composed of quite sophisticated workers. But I think it is possible to advance the hypothesis that many workers went first through a period when strikes over conditions of work predominated, then entered a period when wage strikes took precedence. A recent article discusses this explicitly for mine workers in Silesia. Strikes in Britain over working conditions declined rather steadily in the decades before World War I. ${ }^{1}$ Assuming material conditions above the subsistence level, workers were more easily brought to a concern about changes in traditional work patterns than to a concern for higher pay. Only gradually did they accept the nature of industrial work or at least learn that strikes against it were futile (strikes over conditions consistently were harder to win than strikes over pay). They learned that the pace of work would become more rapid, that work systems would change. I think there was often a period in which many workers who had learned to refrain from strikes against changes in conditions had not yet learned to agitate for compensatory wage rises. ${ }^{2}$ The German workers who expressed such bitter hatred of their work around the turn of the century did not demonstrate great interest in higher standards of living, and their strike rate was modest. Socialism undoubtedly expressed their grievances, but sophisticated strikes were more difficult. But ultimately

1 Schofer, "Patterns of Labor Protest", loc. cit.

2 Stearns, "Adaptation to Industrialisation", pp. 317-21. 
workers learned to accept what Eric Hobsbawm has called a market system of labor, where changes in work methods had to be compensated by wage raises. ${ }^{1}$

Strikes for reduction in hours of work were of course fully as "offensive" as demands for more pay. Union leaders undoubtedly believed that such strikes showed more sophistication than pay strikes. I am not at all sure they were right. We have seen that it took time to develop a market conception of labor. Studies of working-class budgets often do not reveal a huge impulse to improve consumption standards. Most workers, if they began to earn more money than before, obviously improved their spending in most of the traditional categories, but particularly food and clothing. They did not quickly turn to new items of consumption, such as more expensive recreational pursuits England is something of an exception here - or to more expensive housing. ${ }^{2}$

Wage strikes that were unambiguously offensive had four possible bases. One reflected a traditional sense of justice. Workers asked that their pay be raised to that of their fellows in other companies or sometimes other regions. Textile workers in Lille spoke of wanting "Pierre, Paul or Jacques to be paid the same price for the same work". 3 As workers learned more about their fellows this impulse spread widely; it operated most impressively among dockers and other unskilled groups when they awakened to the fact that they were a part, though an underpaid part, of the working class. A newer motive, following from the market labor idea, was to ask for a raise in response to a change in work systems. Dockers again showed an understanding of this principle when they complained that their work was getting harder and asked for more pay to compensate. Printers did the same thing more explicitly when they accepted the new automatic composing machines in return for higher rates. A third impulse could come from rising prices and visible prosperity in the industry itself. Coal miners in particular, who could easily judge the state of their industry by the size of coal stocks, early learned to ask for raises on this basis. The British sliding scale agreements, which pinned wages to coal

1 Eric Hobsbawm, "Customs, Wages and Workloads", in Labouring Men, pp. 406-13.

2 Maurince Halbwachs, La Classe Ouvrière et le niveau de vie (Paris, 1913); Board of Trade, Report of an Enquiry into Working Class Rents, Housing and Retail Prices (London, 1908); Report of an Enquiry into Working Class Rents, Housing and Retail Prices [...] in the Principal Industrial Towns of France (London, 1909), and Report of an Enquiry into Working Class Rents, Housing and Retail Prices [. . ] in the Principal Industrial Towns of Germany (London, 1910).

${ }^{3}$ Léon de Seilhac, La Grève du tissage de Lille (Paris, 1910), p. 63. 
prices, were the most formal expression of this linkage - and of course, as the British miners gradually learned, the linkage did not assure higher real wages. ${ }^{1}$ But the association of wages and the visible prosperity of an industry could help the conversion to an offensive mentality. ${ }^{2}$ Belgian miners were still groping toward it in the prewar years, just when British miners, goaded by inflation, rebelled against the inadequacies of the system..$^{3}$ All of which demonstrates once again that workers did not easily adopt collective improvements in wages as a suitable justification for protest. They did not, for example, normally use employer profits or rising living standards as part of their argument, though their leaders might. Resentment against employer wealth was sometimes expressed in personal terms; more rarely workers complained about their employer's new car when they met during wage strikes. ${ }^{4}$ But this motive was not widespread, and many workers indicated, even as convinced socialists, that material inequality was inevitable, even proper. ${ }^{5}$

Some workers, finally, learned to ask for a raise simply because raises were natural. They no longer needed to invoke rates elsewhere or the changing nature of the work, though these motives may have operated still. Glove workers in Milhaud, France, conducted several wage strikes between 1900 and 1913. Their first efforts were against pay cuts, then against price increases; they did not ask for absolute improvements. But in 1913, spurred by a new American tariff that brought higher prices for gloves, they broke a contract and struck for a substantial raise, justifying their demand in terms of their desire for their "normal and constant raise". ${ }^{6}$

It can be noted that demands for a reduction in work hours must be evaluated on a scale somewhat similar to that of wages. Among many workers they were dictated by a fear of unemployment, a major concern in this period even in presumably prosperous years. British workers, particularly, were driven by this fear; and it was only in

1 R. Page Arnot, The Miners (London, 1949-53); The Miners' Next Step (Tonypandy, 1912).

2 Stearns, Revolutionary Syndicalism, p. 52. Saint-Malo construction workers, learning of a large public works contract, moved to "profit from these millions to be gained in the works under contract, to raise our pay". Archives Nationales, Paris, $F^{7} 13648$.

3 Fédération provinciale des mineurs liégeois, La Vérité sur la grève des mineurs du bassin de Liège en janvier 1911 (Liège, 1911).

4 Léon de Seilhac, Les Grèves du Chambon (Paris, 1912), p. 26.

5 Paul Göhre, Drei Monate Fabrikarbeiter (Leipzig, 1913), p. 113, cites a socialist metalworker who noted: "There will always have to be rich and poor. We would not think of altering that."

- Archives Nationales, $F^{7} 13868$. 
Britain that there were direct demonstrations over unemployment issues. But hours strikes and work slowdowns as a protection against unemployment were common elsewhere. ${ }^{1}$ More directly offensive hours strikes might be motivated by the increasing pace of work. Workers still burdened with 14- or 15-hour days, including groups like barbers as well as the unskilled, sometimes asked for shorter days on grounds of overwork, which was an important step forward. But other hours strikes were simply a circuitous means of getting a raise. Construction workers, especially, often demanded lower hours not to reduce their work day but to win overtime, to the despair of labor leaders who wanted workers to enjoy greater leisure. The hours strike that produced articulate demands for greater leisure was rare indeed, again aside from the pronouncements of labor leaders. But there were a few, and among some artisans, particularly in Germany where the rising pace of work caused most concern, demands for annual vacations began to emerge as well, right before the War.

Insistence on union recognition must also be counted as a highly sophisticated demand in the years before World War I. Occasionally inexperienced strikers raised recognition demands, but more commonly they found them irrelevant or dangerous to their more immediate interests. It was far more likely to have a strike over a union leader dismissed from his job than to have a demand on the principle. Workers more than once tried to get a leader rehired, while promising that union recruitment efforts would cease. So here again was an issue that gained support only slowly among those workers who needed to use strikes to force recognition. The fact that many workers gained union recognition without strikes that raised the demand explicitly is the only qualification to the use of this criterion in measuring strikes. That is, the incidence of strike demands would clearly underrate worker interest in recognition (except perhaps in the United States and Britain, where the demand was unusually common), and this has to be considered when one assesses the relatively small percentage of strikes that raised this issue before 1914 .

We can, then, construct a graded system for evaluating the sophistication of strike demands: the lowest level consists of strictly defensive wage strikes; next come strikes over personal issues; next, defensive strikes over conditions and intermediate wage and hours strikes; next, genuinely offensive wage strikes, the often related demands for a reduction of hours, and on occasion union and solidarity issues.

1 Public Record Office, London, HO 45 B13077A and HO 45 154025; W. G. H. von Reiswitz, Ca' canny (Berlin, 1902). 
This tentative schedule requires just a few more comments. It cannot be used to judge any individual strike, only larger incidences. It cannot be applied with equal success to every industry. It fits most factory industries. But craftsmen probably learned to strike for higher wages before the most rapid transformations of their working conditions around the turn of the century, which then forced a new interest in strikes over such issues without an abandonment of the concern for better pay. The pattern of demands does not preclude a more general reversion to earlier issues, when economic or other conditions dictated, though the few studies available on strikes between the world wars suggest that the evolution continued in the direction indicated, at least until the onset of depression. ${ }^{1}$ The pattern is not intended to preclude subsequent stages in demands - the offensive wage strike may yield to a demand for participation in industrial governance as the "most sophisticated" demand. Above all the pattern is meant to be descriptive, not a judgment of the quality of the evolution. It may be unfortunate that the most sophisticated workers concentrated on wage gains, as opposed to battling for a more humane work system. But their movement in the former direction can be roughly measured and does describe important changes in their outlook. It is for this reason that demands, despite their subjective quality, ought to be added to more formal aspects of strike activity in measuring the evolution of labor protest.

\section{VI}

\section{THE CHARACTERISTICS COMBINED}

We can obviously expect significant correlation between demands and other characteristics of strikes. Before World War I offensive and intermediate wage strikes, for example, were larger than personal issue or defensive strikes and more likely to transcend a single company. Strikes for reductions of hours even more clearly assumed advanced forms. In Austria between 1899 and 1910 only $16 \%$ of all one-company strikes dealt with this issue, whereas $49 \%$ of the multi-company strikes did so. On personal issues the contrast was reversed $(29 \%$ compared to $3 \%$ ). Where correlations break down, there is an obvious target for explanatory research. Again in Austria, percentage of participation was slightly below the overall norm in hours strikes, and higher in personal issue strikes. The reason seems to be that a minority of workers developed more sophisticated demands, which they could carry across company lines but which were not as attractive to the

1 Goetz-Girey, passim. 
bulk of the relevant workforce as more traditional grievances. ${ }^{1}$ Strikes in the United States around the turn of the century show considerable sophistication in size, organization, and number of companies affected, but they lagged in the matter of timing, tending to bunch in years of recession. British strikes were more sophisticated in forms than in demands. They were much larger than their counterparts in France and Germany (averaging over 550 workers per effort), much more likely to be multi-company and so on; but only slightly over half of all strikers sought a wage increase, while more strikers (at 9\%) struck over personal issues than for a reduction in hours. ${ }^{2}$ The inflationinspired outburst after 1909, which was essentially defensive, confirms the impression that the grievances of British workers had changed less rapidly than their tactical and organizational knowledge.

Examples of this sort also point up the tentativeness of the criteria suggested in this essay for measuring the evolution of strikes. Further study may show that some deviations from the norm call the norm itself into question. There is no doubt that there were reverses in the general evolution of strikes and that the evolution itself was often slow. Between 1899 and 1914 in France and Germany, the average size of strikes rose only slightly and strike duration changed very little. Union involvement increased, but in France fell off after a peak in 1906. Collective bargaining spread; violence may have declined in France, but certainly not in Germany (or Britain). Defensive wage strikes declined in France but they actually rose in Germany as a percentage of the total. This was clearly a transitional period for strikes. Many workers were striking for the first time, while others, including some of the best organized, withdrew from the strike arena. Hence the halting evolution. But this very gradualness emphasizes the importance of developing clear measurements of strike patterns, for we cannot assume that strikes quickly became "modern" according to the models that have been developed thus far. We must chart their various stages in order to understand the history of workers' mentality.

Furthermore, within any given period the evaluation of strike patterns allows comparisons from one area to the next and from one industry to the next, and these in turn set goals for a deeper study of causes. By almost all the standards of measurement suggested, from strike rate to strike size to patterns of demands, French workers displayed greater sophistication than Germans or Belgians before World War I. This reflects France's protest tradition, but it may seem surprising in view of France's rate of industrial development. On fur-

1 John G. Niesz, "Behavioral Variation in Austrian Strikes" (unpublished seminar paper, Rutgers Unversity, 1972).

2 Board of Trade, Annual Reports on Strikes, 1899-1914. 
ther examination the comparison leads to the conclusion that France's industrial development was not so laggard, from the workers' standpoint. French companies in many industries were larger than their German counterparts. ${ }^{1}$ French workers were also more thoroughly urban; here the comparison of strike pattern encourages analysis of residential patterns, the outlook of working-class wives (who could be vital to the formulation of wage demands), the origins and age structure of the working class, and so on. Comparisons between types of workers in the same area can be equally revealing ${ }^{2}$. They suggest the continuing distinction in basic values between artisans and factory workers, despite often common participation in the labor movement. Even among factory workers they raise fascinating analytical questions. Why do metallurgical workers strike so much less frequently and with so much less sophistication than miners? Here again evaluation of strike patterns serves as a point of entry to a more profound understanding of working-class life.

For any descriptive model for assessing strike patterns raises more questions than it resolves. Like the model of preindustrial protest, ${ }^{3}$ it invites deeper penetration into working-class culture, because the model itself is inherently superficial. Wage strikes, even if divided into defensive, intermediate, and offensive, cover a multitude of situations. The Ruhr mine strike of 1905, listed as a wage strike, in fact expressed profound uneasiness about changes in working conditions and the concentration of mine ownership, plus the hardships caused by a worm disease and its treatment. ${ }^{4}$ Measuring protest by the methods outlined above delineates but the tip of an iceberg. Yet because even the surface characteristics of strikes varied significantly from case to case and because they did evolve in ways that suggest important changes in the working class, their evaluation is a vital starting point. The fact that their study remains open-ended is not surprising, given their long neglect by historians. Because strikes can, to a much greater degree than formal labor movements, be assessed in terms of standard criteria, their analysis not only advances our understanding of protest but also refines the questions we should be asking about working-class culture.

1 Peter N. Stearns, "National Character and European Labor History", in: Journal of Social History, IV (1970-71), pp. 95-124.

"Kerr and Siegel, "The Interindustry Propensity to Strike", loc. cit.

3 E. P. Thompson, "The Moral Economy of the English Crowd in the Eighteenth Century", in: Past and Present, No 50 (1971), pp. 76-136.

- Fricke, Bergarbeiter-Streik; Heinrich Munz, Die Lage der Bergarbeiter im Ruhrrevier (Essen, 1909); Hauptstaatsarchiv Düsseldorf, Politische Akten 15915-6, reports on miners' agitation 1899-1905; Staatsarchiv Münster, Regierung Arnsberg I, 84, reports of the Oberbergamt Dortmund on agitation over the worm epidemic. 